\title{
The Social Network of Alcohol Users Undergoing Treatment in a Mental Health Service
}

\author{
Jacqueline de Souza ${ }^{1}$ \\ Luciane Prado Kantorski² \\ Gabriela Pereira Vasters ${ }^{3}$ \\ Margarita Antonia Villar Luis ${ }^{4}$
}

The treatment of alcohol and drug users requires an extended reflection on the influence of the family and other social network groups of these individuals. Thus, this study, results of a qualitative study, aimed at investigating the presence of drug users in the social network of individuals undergoing treatment and the possible interventions of the mental health services in the social network of four users of alcohol in the municipality of Alegrete/ RS. Interviews with users and families, genograms and eco-maps were used. The results indicated the presence of drug users in the family and in the other social network groups, and that the group for chemical dependants was the main intervention in these social networks. These results demonstrate the need for directing the actions of mental health to develop healthy bonds, to expand the social network and structure of the group in order to provide benefits which favor effective psychosocial rehabilitation.

Descriptors: Substance-Related Disorders; Mental Health Services; Social Support.

\footnotetext{
${ }^{1}$ RN, Doctoral Student, Escola de Enfermagem de Ribeirão Preto, Universidade de São Paulo, WHO Collaborating Centre for Nursing Research Development, SP, Brazil. E-mail: jacsouza2003@yahoo.com.br.

${ }^{2}$ RN, Ph.D. in Nursing, Adjunct Professor, Faculdade de Enfermagem e Obstetrícia, Universidade Federal de Pelotas, RS, Brazil. E-mail: kantorski@uol.com.br.

${ }^{3}$ Occupational Therapist, Master's Student, Escola de Enfermagem de Ribeirão Preto, Universidade de São Paulo, WHO Collaborating Centre for Nursing Research Development, SP, Brazil. E-mail: gabi_vasters@yahoo.com.br.

${ }^{4}$ RN, Ph.D. in Nursing, Full Professor, Escola de Enfermagem de Ribeirão Preto, Universidade de São Paulo, WHO Collaborating Centre for Nursing Research Development, SP, Brazil. E-mail: margarit@eerp.usp.br.
}

Corresponding Author:

Margarita Antonia Villar Luis

Universidade de São Paulo. Escola de Enfermagem de Ribeirão Preto.

Departamento de Enfermagem Psiquiátrica e Ciências Humanas.

Av. dos Bandeirantes, 3900

Bairro Monte Alegre

CEP: 14.040-902 Ribeirão Preto, SP, Brasi

E-mail: margarit@eerp.usp.br 


\section{Rede social de usuários de álcool, sob tratamento, em um serviço de saúde mental}

O tratamento de usuários de álcool e drogas requer reflexão ampliada sobre a influência da família e outros grupos da rede social desses indivíduos. Assim, este estudo, resultado de pesquisa qualitativa, objetivou averiguar a presença de usuários de drogas na rede social de indivíduos sob tratamento e as possíveis intervenções do serviço de saúde mental, na rede social de quatro usuários de álcool, no município de Alegrete, RS. Foram utilizadas entrevistas com usuários e familiares, genograma e ecomapa. Os resultados indicaram a presença de usuários de drogas na família e demais grupos das redes sociais e o grupo para dependentes químicos como principal intervenção nessas redes sociais. Os resultados evidenciam a necessidade de direcionamento das ações de saúde mental para o desenvolvimento de vínculos saudáveis, ampliação da rede social e estruturação do grupo, de modo a proporcionar benefícios em prol de efetiva reabilitação psicossocial.

Descritores: Transtornos Relacionados ao uso de Substâncias; Serviços de Saúde Mental; Apoio Social.

\section{Red social de adictos al alcohol bajo tratamiento en un servicio de salud mental}

El tratamiento de adictos al alcohol y drogas requiere una reflexión amplia sobre la influencia de la familia y otros grupos de la red social de estos individuos. Así, este estudio, resultado de una investigación cualitativa, objetivó averiguar la presencia de usuarios de drogas en la red social de individuos bajo tratamiento y las posibles intervenciones del servicio de salud mental en la red social de cuatro adictos al alcohol en el municipio de Alegrete/ RS. Fueron utilizadas entrevistas con adictos y familiares, genograma y ecomapa. Los resultados indicaron la presencia de adictos de drogas en la familia y demás grupos de las redes sociales y el grupo para dependientes químicos como principal intervención en estas redes sociales. Estos resultados evidencian la necesidad de dirigir las acciones de salud mental para el desarrollo de vínculos saludables, ampliación de la red social y estructuración del grupo de modo a proporcionar beneficios en pro de una efectiva rehabilitación psicosocial.

Descriptores: Trastornos Relacionados con Sustancias; Servicios de Salud Mental; Apoyo Social.

\section{Introduction}

The abusive use of drugs is currently a polemic topic of multi-disciplinary debate both within the academic sphere and the professional practices, involving scholars from different areas of knowledge such as rights, health, social sciences, and anthropology, amongst others. The justification for the involvement of these areas relates to the different repercussions of such issues in current society that have raised concerns regarding the microsocial dimensions such as the individual, family, local community, and the macro-social: society, the health system, security, the legal system, and the economic system.

Studies(1) undertaken in a joint effort to understand how the different dimensions are articulated in the face of such problems have not yet been sufficient to clarify when the socio-economic and cultural factors position themselves as a cause or consequence of the progressive increase in the severity of the repercussions related to the consumption, production and distribution of drugs, both licit and illicit. Furthermore, although 
having the agenda of multidisciplinary discussions, the policies and current guidelines on drugs, a global concept, have not proved very effective because there is no single model capable of responding to all demands arising from drug abuse, nor to contemplate resolutive actions in the sphere of the methods of treatment, social rehabilitation and prevention. Furthermore, the complex transformations of modern society and the global trends of dilution of cultural specificities, added to the aesthetic and financial appeal associated with pleasure and immediate happiness, contradictory to the movement of massification and to the denial of the public at the expense of private interests, are aggravating factors that hamper the clear understanding of the problem of drug abuse and other phenomena related to mental health and human interactions.

It appears that, the drug phenomenon, especially the issue of their abuse, and considering the social determinants of health, constitutes a complex problem with implications in the individual and the public sphere. Such complexity requires the planning of health promotion interventions focused on empowerment of the subjects. For this, the basic needs of the individuals must be previously assured by public policies that ensure food, health, education, leisure and work, because only after those needs are met can interventions in social relationships become effective.

Although the interventions in the social relationships of the subjects should be associated with the guarantee of the basic needs of the individuals, they have a priority character, especially considering the psychosocial consequences that permeate the issue of psychoactive drugs in the affective and familiar contexts of the individuals involved with these substances and in the community where they live culminating in social harm that demands, therefore, interventions that address these different contexts. Based on these assumptions, it is emphasized that, in the context of the alcohol and drug problem, there is a pressing need to shift the focus of action from solely the conduct of the user and extend it to the set of relationships that lead the individual to activities prejudicial to the economic, productive, legal, affective and moral spheres ${ }^{(2)}$. Thus, the contextualization of the problem of drug dependency urges an expanded reflection regarding treatment, considering the influence of the family and other groups of the social network triggered by this individual, whether in the route of dependence or in the process of treatment and maintenance of abstinence or of the consumption of the substance under some level of control.

This study is the result of a qualitative study on the social networks of individuals under treatment for psychoactive substance abuse in a mental health service, aiming to verify the presence of drug users in the social networks of such individuals under treatment and the interventions of this service in the social network of its users. This research was part of a study evaluating the Psychosocial Care Centers of Southern Brazil coordinated by the Faculty of Nursing of the Federal University of Pelotas/RS*.

\section{Methodology}

Study subjects were four users, and their respective families, who volunteered for this study. The ethical aspects of research involving humans were observed in accordance with the Resolution no. 196/96 of the National Health Council of the Ministry of Health

The data collection instruments used were a semistructured interview with open questions relative to the user and family focusing on the possible interventions of the mental health services in the social network of the subjects. In addition, qualitative tools, recommended by the Guide to Evaluation and Intervention in the Family(3): genogram and eco-map, were used in order to obtain specific information from the family circle and social network of the individuals.

The semi-structured interview is carried out using some basic questions, supported by theories and hypotheses. The semi-structured interview, at the same time as allowing the relevance in the situation of the actor, maintains the conscious and active presence of the researcher facilitating the description of the social phenomena, the explanation and comprehension of the totality in the specific situation and in situations of greater dimensions ${ }^{(4)}$.

Instruments such as the genogram and eco-map make an important contribution to the understanding of the various components of the social support network. They constitute effective tools that contribute to the understanding of the various components of the social support network of the subject. The genogram is a family diagram that configures the intergenerational structure of the family relationships, the eco-map, in turn, refers to a diagram of the family in contact with other groups: people, agencies, institutions ${ }^{(5)}$. The genogram allows the

* Work linked to the research project "Evaluation of Psychosocial Care Centers in Southern Brazil" - Supported by the Ministry of Science and Technology CNPq / Ministry of Health - SCTIE-DECIT/CT - Saúde 07/2005. 
detailing of the family structure to provide information on the roles of its members in the different generations; its construction is performed through the representation of individuals with symbols (squares correspond to the men and circles to the women) considering their position and role in the family constitution ${ }^{(6)}$

The eco-map was used in order to obtain data regarding the relationships of the individual and/or family with the other systems; this instrument has visual impact as its primary value. For its design the family genogram is placed in a central circle and circles are constructed around this representing people, agencies or institutions that contextualize the individual and their family; lines are then drawn between the individual and/ or family and the external circles to indicate the nature of existing affective bonds ${ }^{(3)}$.

From this perspective, the genogram and eco-map were constructed with the users and their families in order to identify the intra (genealogy) and extra-familial (eco-map) bonds, allowing the elucidation of the social support network of the individual. The interviews with family members and users, in addition to expanding the view of these interventions, highlighted the main demands of this group. As a resource for summarizing the data Sociometry guidelines ${ }^{(7)}$ were used in order to present the main characteristics of the family circle and the social network, synthesized in four sociograms of the respective individuals and presented in Figures 1 and 2 within the results. It is emphasized that in order to facilitate the presentation of the results in an objective and concise way, the data obtained from the eco-map will be preferential, because its construction is carried out from the prior elaboration of the genogram, and its findings relate to the constitution of the networks.

The set of data allowed reflection on the social network of the psychoactive substance users in treatment who participated in the study. These data were analyzed taking as parameters the Calgary Family Assessment Model guidelines and the current literature referring to the social network and drug use. The Calgary Family Assessment Model (CFAM) ${ }^{(3)}$ is a structure of multidimensional and integrated assessment that has systems theory as its basis. Evaluation under this model is divided into three main categories: I. Structural Assessment: who is part of the family, the affective bonds between the members and the family context (genogram and eco-map); II. Evaluation of Development: stage of the life cycle (path) in which the family is found, III. Functional Assessment: the basic aspects of family functioning, quotidian activities and aspects related to family communication. Thus, the present study adopted the category of structural evaluation with emphasis on the internal structure subcategories: family composition, gender, subsystems (subgroups formed within the family system); and the external structure: the wider systems (social institutions and people with which the family has significant contact).

\section{Results}

Interviewees were alcohol users, unemployed, without a marital bond, although over 35 years of age, currently living with parents or a nuclear family constituted by some of the siblings, according to Table 1 .

Table 1 - General characteristics and data regarding treatment and abstinence from alcohol of the participants (the individual's age is cited in brackets)

\begin{tabular}{|c|c|c|c|c|}
\hline Subject's data & Subject 1 & Subject 2 & Subject 3 & Subject 4 \\
\hline Age & 37 & 35 & 56 & 45 \\
\hline Marital status & Single & Single & Separated & Separated \\
\hline Accompanied by & Mother & Mother & Sister & Brother \\
\hline Lives with & $\begin{array}{l}\text { Mother (66), sister (22), brother } \\
\text { (25) and nephew (4) }\end{array}$ & $\begin{array}{l}\text { Father ( } 67) \text {, mother ( } 65 \\
\text { smoker), brother ( } 37) \text { and uncle } \\
\text { ( } 68 \text { ex-alcoholic) }\end{array}$ & $\begin{array}{l}\text { Sister (48 depressive) } \\
\text { and brother (44) }\end{array}$ & $\begin{array}{l}\text { Mother ( } 64 \text { cardiac } \\
\text { problems), brother ( } 39 \\
\text { drug user) }\end{array}$ \\
\hline Living parents & Mother & Father and mother & No & Mother \\
\hline No. of siblings & 8 & 7 & 5 & 7 \\
\hline No. of children & 0 & 0 & 1 adopted daughter (28) & $\begin{array}{l}2 \text { sons ( } 17 \text { and } 23) \text { and } 2 \\
\text { daughters ( } 21 \text { and } 26)\end{array}$ \\
\hline Profession & Builder and electrician & General services & $\begin{array}{l}\text { Bar attendant, screen } \\
\text { printer }\end{array}$ & Builder \\
\hline Employment situation & Unemployed & Unemployed & Unemployed & Unemployed \\
\hline Alcoholism in the family & Father, brother, cousin & Grandfather, uncles & No & 5 siblings \\
\hline Previous treatment & $\begin{array}{l}\text { Yes, Center for Psychosocial } \\
\text { Care (CAPS) }\end{array}$ & Yes, Therapeutic community & $\begin{array}{l}\text { Yes, Center for Chemical } \\
\text { Dependence Care } \\
\text { (CADEQ) }\end{array}$ & No \\
\hline Time of abstinence & 2 months & 2 months & 15 days & 2 years \\
\hline
\end{tabular}

Source: Data of interviewees, genogram and eco-map 
In Figures 1 and 2 the social networks of the study subjects may be observed; the information regarding the interpersonal bonds that these individuals established was obtained from interviews with the patient and companion and the development of the genogram and eco-map:

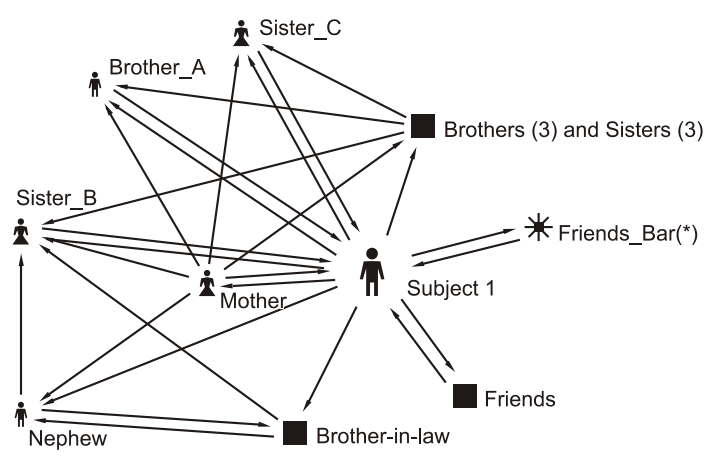

$\left(^{*}\right)=$ alcohol or other drug user

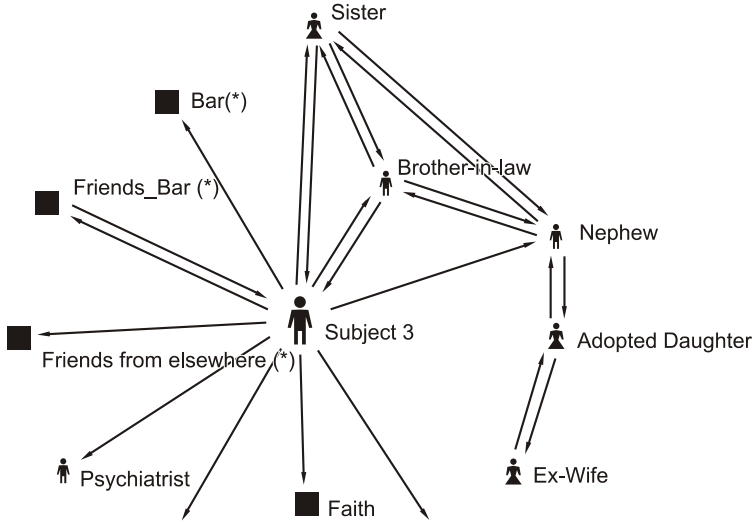

Friends from the city $\left(^{*}\right) \quad$ Siblings
i. Man
Presence of relatioship
i Woman
$\rightleftarrows$ Strong bond

Group of people

* Stressful bond

Figure 1 - Social Network of subjects 1 and 3 (restricted to family members and friends and with substance users in the network - the number of people in the groups are given in parentheses)
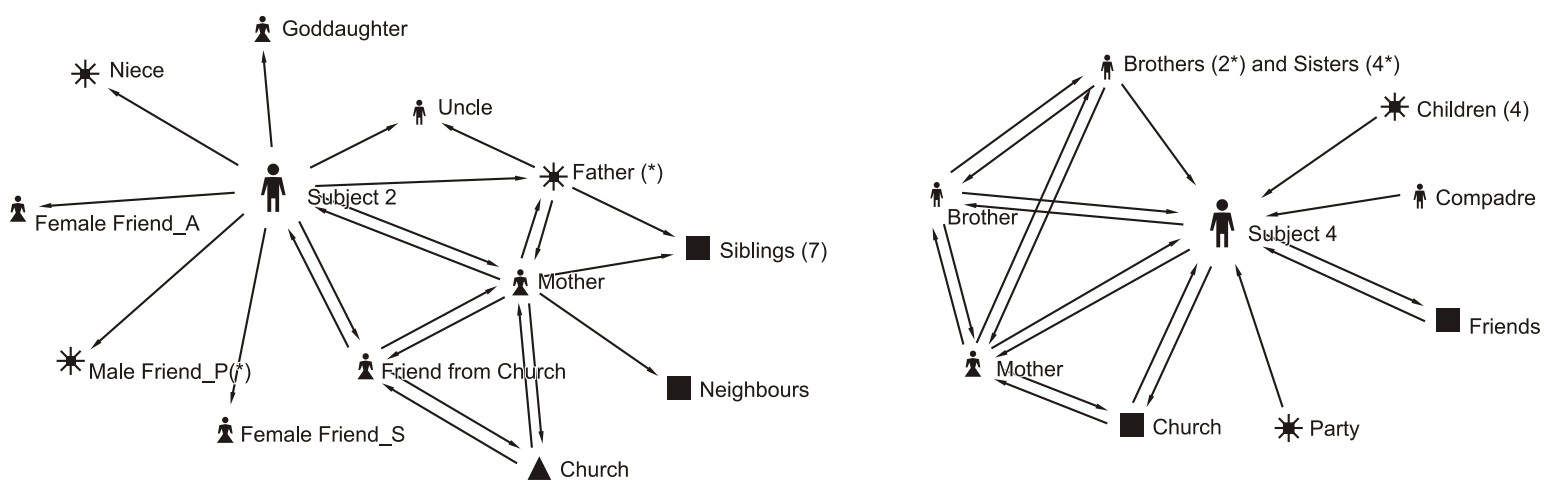

$\left({ }^{*}\right)=$ alcohol or other drug user
i. Man
Presence of relatioship
i Woman

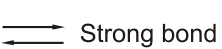
Group of people
米 Stressful bond

Figure 2 - Social Network of subjects 2 and 4 
Among the treatment strategies offered by the service studied, the group for chemical dependents was identified by interviewees as an intervention instrument in their social networks, considering the potentialities identified in the interviews as observed in Table 2.

Table 2 - Summary of the history of social interactions of the subjects in the context of treatment

\begin{tabular}{|c|c|c|c|c|}
\hline Subjects/Items & Subject 1 & Subject 2 & Subject 3 & Subject 4 \\
\hline $\begin{array}{l}\text { Main subsystems of the } \\
\text { social network }\end{array}$ & $\begin{array}{l}\text { I. Brother-in-law, sister_B and } \\
\text { nephew II. Brothers, subject } \\
1 \text { and mother; III. Mother, } \\
\text { sister_B and subject } 1\end{array}$ & $\begin{array}{l}\text { I. Subject 2, friend from church } \\
\text { and mother; II. Mother, friend } \\
\text { from church and church; III. } \\
\text { Father, mother and siblings }\end{array}$ & $\begin{array}{l}\text { I. Subject 3, sister, } \\
\text { brother-in-law and } \\
\text { nephew }\end{array}$ & $\begin{array}{l}\text { I. Subject } 4 \text {, mother and } \\
\text { church; II. Mother, siblings } \\
\text { and subject } 4\end{array}$ \\
\hline Wider systems & $\begin{array}{l}\text { I. Bar; II. Friends; } \\
\text { III. CADEQ. }\end{array}$ & $\begin{array}{l}\text { I. Friends; II. Church; III. } \\
\text { CADEQ }\end{array}$ & $\begin{array}{l}\text { I. Bar; II. Friends; III. } \\
\text { CADEQ }\end{array}$ & $\begin{array}{l}\text { I. Church; II. Party } \\
\text { Affiliation; III. Friends; IV. } \\
\text { CADEQ }\end{array}$ \\
\hline Supporting bonds & Siblings & $\begin{array}{l}\text { Father, mother and a female } \\
\text { friend }\end{array}$ & Sister & Siblings, godfather, church \\
\hline $\begin{array}{l}\text { Relation with friends that } \\
\text { are users of alcohol or } \\
\text { other drugs }\end{array}$ & Yes "drinking companions" & $\begin{array}{l}\text { Avoids colleagues who he } \\
\text { drank with; has two female } \\
\text { friends who do not use drugs }\end{array}$ & $\begin{array}{l}\text { Drug user friends in } \\
\text { treatment; }\end{array}$ & $\begin{array}{l}\text { Fishing Friends, } \\
\text { colleagues from church } \\
\text { and from the political party } \\
\text { to which he is affiliated }\end{array}$ \\
\hline $\begin{array}{l}\text { Environments } \\
\text { frequented }\end{array}$ & $\begin{array}{l}\text { Male friend's house (alcoholic } \\
\text { in treatment), bars, CADEQ }\end{array}$ & $\begin{array}{l}\text { Female friends' house, church, } \\
\text { CADEQ }\end{array}$ & $\begin{array}{l}\text { Bar, parties, parent's } \\
\text { house, CADEQ }\end{array}$ & $\begin{array}{l}\text { Fishing, friend's and } \\
\text { parent's houses, church, } \\
\text { Party headquarters, } \\
\text { CADEQ }\end{array}$ \\
\hline $\begin{array}{l}\text { Potentialities highlighted } \\
\text { in relation to the group } \\
\text { for chemical dependants }\end{array}$ & $\begin{array}{l}\text { Opportunity to make friends; } \\
\text { medical and medicine } \\
\text { monitoring }\end{array}$ & $\begin{array}{l}\text { Know similar realities; the } \\
\text { possibility of interaction with } \\
\text { other people }\end{array}$ & Source of instruction & $\begin{array}{l}\text { Opportunity of interaction; } \\
\text { reference of health care as } \\
\text { a whole }\end{array}$ \\
\hline
\end{tabular}

Source: Data of interviewees, genogram and eco-map

CADEQ: Center for Chemical Dependence Care

\section{Discussion}

The unemployment situation of the subjects, as seen in Table 1, highlights the problem of social inequality as a present reality in the country, where society possesses inequality as a most striking feature and, although social indicators have shown widespread improvement, a still very large social disparity. Half the population of Brazil has an income (monthly average of all jobs) of half to two minimum wages; the richest $1 \%$ of the population accumulates the same amount of income as the poorest $50 \%$; and the richest $10 \%$ earns 18 times more than the poorest $40 \%$. Half the Brazilian workers earn up to twice the minimum wage( ${ }^{(8)}$.

Given that the mental health service to individuals with problems caused by alcohol or other drug use mentioned in this study is a public body, it is emphasized that, although the Brazilian National Health Service (SUS) adopts the principle of universal access to health services without any Socioeconomic distinction, the majority of users treated at the centers of mental health care correspond to groups in situations of social vulnerability. The exclusion from the working world is indeed a social risk situation that has spread in the contexts of globalization of the economy and of poverty; the social vulnerability due to this exclusion consists of a circular process that starts from the impossibility of self-provision of basic conditions that ultimately leads to the disruption of social ties: family, friendships and other community relationships ${ }^{(9)}$. Thus, the pertinence is confirmed of the preconization of the current policies of which the interventions related to problems resulting from the use of alcohol and drugs have a community focus aimed at the social networks so as to enable the citizen action of these users, especially regarding the reversal of the adverse consequences of the current social exclusion that tends to increase the complexity of mental health problems and the phenomenon of drug abuse.

The subjects of the study have a social network restricted, in general, to the family, friends or former friends who are also drug users, all have undergone previous treatment, have a history of relapses and restricted affective bonds. In this sense, a pressing need is highlighted for interventions designed to develop healthy relationships in order to expand the resources and potentialities of the social network ${ }^{(10-11)}$. Therefore, a treatment where the ultimate objective is the reduction 
of drug use, all of these interactional resources require restructuring, in the case of dependence some bonds necessarily need to be broken (such as friends and companions of use), other strengthened or remade (such as family bonds, usually broken due to complications during the dependence process) and others, in turn, constructed (new friendships, new environments and leisure activities, new affective ties).

Regarding the presence of other drug users in the social network, this is considered a risk factor for relapse or discontinuity of treatment; results ${ }^{(12)}$ highlight impairment in the social network of the individuals who had drug users in the network, i.e. their influences were more strongly associated with continued drug use by the individuals than with any beneficial effect coming from the social network of the participants such as the frequency of contacts or the availability of support. Another scientific finding(13) also indicated that the clients whose spouses or significant others were abusing alcohol or drugs in the post-discharge period were more likely to relapse, suggesting that to help clients improve and construct their social networks during treatment optimizes the results of this. In relation to leisure activities, two of the subjects mentioned frequenting the bar as a form of entertainment and the two that did not mention the bar, mentioned some form of religious practice. Alcohol use as entertainment demands the resumption of the discussion that, apart from being legal in the country, alcohol is a drug of low cost and is extremely accessible with regard to its distribution, which is reflected in its diffusion throughout all layers of the population including through the encouragement of television media(14). Therefore, considering the individual dependent on substances that totally restrict their leisure activities to drug use, the context of abstinence reduces the opportunities for entertainment, especially in the current society in which, as previously described, many pleasure activities are associated with the use of alcohol.

Conversely, the issue of religion has the role of spirituality for the subject and may have the role of making possible interactions, controlling the use, and creating an environment of socialization. Religion or spirituality has been described as a source of social support, i.e. as an incentive to practices and values advocated by religious groups which include: control of the impulses and practice of fraternity, and may promote socialization, healthy behavior and ways of making sense of their experiences and anxieties ${ }^{(3,15)}$.

Regarding the group for chemical dependents, as described in Table 2, the subjects of this study described it as a possibility to interact with people in similar situations, a reference and for health care and a source of instructions. Treatment in groups is currently a strategy widely used by the mental health services, due to its possibility to optimize time, and for its favorable contributions in the rehabilitation of users. It is emphasized that group work has the potential to provide real and emotional support to participants, to reduce the risk of isolation, to encourage the exchange of experiences, to provide opportunities for the development of personal and social skills and, ultimately, to be the basis for the process of awareness and engagement in treatment(14). Moreover, the groups have support functions by providing social inclusion, strengthening autonomy, self-esteem and personal empowerment, performing the role of a social network and being spaces for education and health for their participants ${ }^{(16)}$. Based on experiences of group treatment, it was observed that the group participants experience movements such as: a challenge to speak and express their pain in front of the other, to listen to the pain of somebody else, to question themselves about themselves, about the others and about the world. Therefore, the group provides the identification of the users with each other, since many verbalized symptoms and problems are common ${ }^{(17)}$. However, it should also be considered that all the benefits of the group can be neutralized if certain minimum rules of establishment and operation are not observed, such as regarding the number of participants, very large groups may favor the manifestation of those with more ease of expression limiting or disparaging the others; regarding gender, groups including both sexes can inhibit the expression of the women; regarding age, groups composed of adults and adolescents may impede the adhesion of the latter to the meetings. Therefore, the professional should not forget that each individual is unique with their experiences and history, and this should be taken into account at the moment of developing the treatment plan, evaluating the best moment to insert them into a group and whether this mode of care is applicable to their case.

\section{Conclusion}

The real influence of family history of chemical dependence, of the presence of drug users in the social network and of restricted social environments were highlighted as negative interference in the process of treating these individuals. These factors highlight the need for mental health services to direct their actions toward 
socialization skills and interventions that contribute to improving the quality of the bonds and eventually the expansion of the social network. Furthermore, the development of healthy bonds outside the service must be added to the benefits that the therapeutic group needs to offer to really favor psychosocial rehabilitation, which constitutes a local facilitator for the expression of suffering, fears, successes and expectations of the participants; ultimately, a gregarious space of effective welcome, able to empower the social support network of the participants.

\section{References}

1. Luis MAV, Lunetta ACF. Álcool e outras drogas: levantamento preliminar sobre a pesquisa produzida no Brasil pela enfermagem. Rev. Latino-Am. Enfermagem. 2005; 3(número especial):1229-30.

2. Nascimento $A B$. Uma visão crítica das políticas de descriminalização e de patologização do usuário de drogas. Psicol Estudo. 2006;11(1):185-90.

3. Wright LM, Leahey M. Enfermeiras e Famílias: um guia para avaliação e intervenção na família. São Paulo: Roca; 2002.

4. Triviños ARS. Introdução à pesquisa em ciências sociais: a pesquisa qualitativa em educação. São Paulo: Atlas; 1998.

5. Roth P. Family Social Support. In: Bomar PJ. Nurses and Family Health Promotion: concepts, assessment and interventions. Philadelphia: WB Saunders; 1996.

6. Rocha SMM, Nascimento LC, Lima RAG. Enfermagem pediátrica e abordagem da família: subsídios para o ensino de graduação. Rev. Latino-Am. Enfermagem. 2002; 10(5):709-14.

7. Moreno JL. Quem Sobreviverá? Fundamentos da Sociometria, Psicoterapia de Grupo e Sociodrama. Goiânia: Dimensão Editora; 1992.

8. Instituto Brasileiro de Geografia e Estatística. Síntese de Indicadores Sociais. Rio de Janeiro; 2002.

9. Inojosa RM. Saúde: esgarçamento e reconstituição da rede social. Rev Admin Pública. 2000; 34(6):105-16.

10. Souza J, Kantorski LP. A rede social de indivíduos sob tratamento em um CAPS AD: O Ecomapa como recurso. Rev Esc Enfermagem USP. 2009; 43(2):373-83.

11. Carranza DVV, Pedrao LJ. Satisfação pessoal do adolescente adido às drogas no ambiente familiar durante a fase de tratamento em um instituto de saúde mental. Rev. Latino-Am. Enfermagem. 2005;13(n. esp.):836-44.
12. Schroeder JR, Latkin CA, HooverD, Curry AD, Knowton AR, Celentano DD. Ilicit Drug Use in One's Social Network and in One's Neighborhood Predicts Individual Heroin and Cocaine Use. Ann Epidemiol. 2001;11(6):389-94.

13. Ellis B, Bernichon $T, Y u$ P, Roberts $T$, Herrell JM. Effect of social support on substance abuse relapse in a residential treatment setting for women. Eval Program Plann. 2004; 27(2):213-21.

14. Pinsky I, Bessa MA, organizadores. Adolescência e drogas. São Paulo: Editora Contexto; 2004.

15. Dias J, Nascimento LC, Mender IJM, Rocha SMM. Promoção de saúde das famílias de docentes de enfermagem: apoio, rede social e papéis na família. Texto Contexto Enferm. 2007;16(4):688-95.

16. Teixeira MB, Lima ED. Grupos como uma estratégia do programa de saúde da família e como dispositivo no campo da saúde mental. ACADEMUS Rev Científica Saúde. 2005; 4(1):39-56.

17. Costa-Rosa A, Luzio CA, Mender MCS, Florezi P. Uma experiência de Pronto Atendimento em saúde mental coletiva. Estudos Psicol PUC. 2004;21(2):101-15.
Received: Nov. $3^{\text {rd }} 2009$

Accepted: Sep. 30 2010 